\title{
THE USE OF CHILDREN IN COCOA PRODUCTION IN SEKYERE SOUTH DISTRICT IN ASHANTI REGION, GHANA: IS THIS CHILD LABOUR OR AN APPRENTICESHIP TRAINING?
}

\author{
P.K.B. Asamoah1, S.B. Adubofour ${ }^{2}$, J. Obodai ${ }^{3 *}$ and F.O. Agyemang ${ }^{3}$ \\ Received 21 February 2018, Revised 7 June 2018, Accepted 26 June 2018, Published online 30 June 2018
}

\begin{abstract}
Concerns have been growing in Ghana about the employment of children, aged between 5-17 years, in cocoa production activities. This concern is echoed by the International Labour Organisation in its attempt to eliminate Worst Form of Child Labour. The objectives of the study were as to: investigate whether the labour of the children are paid for; determine the extent of children's involvement; and investigate the risks they are exposed to. Using Focus Group Discussions (FGDs), participant groups made up of women, men, children and opinion leaders were purposely selected from 10 cocoa producing communities from the study area. Structured questionnaires were also administered to 50 cocoa farmers through face-to-face interviews. The study revealed that harvesting is the stage in the cocoa production process that children are directly and actively involved. The study concludes by indicating that child labour and cocoa production are inseparable in the cocoa producing areas in the study site.
\end{abstract}

Keywords: Cocoa Farming, Child Labour, Cocoa Production, Apprenticeship Training

${ }^{1}$ Centre for Settlements Studies, College of Art and Built Environment, Kwame Nkrumah University of Science and Technology, Kumasi-Ghana

${ }^{2}$ Department of Theology, Christian Service University College, Kumasi-Ghana

${ }^{3}$ Department of Planning and Development Studies, Christian Service University College, Kumasi-Ghana

*Corresponding author's email: jacobobodai@gmail.com (J. Obodai)

\section{Introduction}

Considerable differences exist between the many kinds of work children do (Augendra, 2008). Some are difficult and demanding, others are more hazardous and even morally reprehensible. Children carry out a very wide range of tasks and activities when they work. This has given rise to a myriad of definition based on the kind of work children are involved (ILO, 2007b).

Child labour has variously been defined by different authors and international organisations. The International Labour Organization (ILO, 2007a) defines child labour as work that deprives children of their childhood, their potential and their dignity, and that is harmful to their physical and mental development. Not all work done by children should be classified as child labour and targeted for elimination (Emerson and Souza, 2011; J ean-Marie and Robinson, 2000; Basu and Zarghamee, 2009). Children's or adolescents' participation in work that does not affect their health and personal development or interfere with their schooling is generally regarded as being something positive (Franziska, 2009; Ravallion and Wodon, 2000). This includes activities such as helping their parents around the home, assisting in a family business or earning pocket money outside school hours and during school holidays. These kinds of activities contribute to children's development and to the welfare of their families; they provide them with skills and experience, and help to prepare them adequately to enable the children to be productive members of society during their adult life (Bass, 2004; Watson, 2008).

In its most extreme forms, child labour involves children being enslaved, separated from their families, exposed to serious hazards and illnesses and/or left to fend for themselves on the streets of large cities - often at a very early age. Whether or not particular forms of "work" can be called "child labour" depends on the child's age, the type and hours of work performed, the conditions under which it is performed and the objectives pursued by individual countries. The answer varies from country to country, as well as among sectors within countries (Humphries, 2010; ILO, 2007a). Child workers are basically involved in three main sectors, namely, i) agriculture sector where children's activities are in farming, hunting, forestry, and fishing; ii) the industrial sector, which includes mining and quarrying, manufacturing and construction; and iii) the 
service sector, consisting of wholesale and retail trade, restaurants and hotels, transport, communication and social personal services. Of importance to this paper is child labour in the agriculture sector and specifically in cocoa farming or production

In Ghana the use of child labour in cocoa production dates back to the 1930s when the cocoa farming industry gained prominence among the farming populace in Ashanti Region. This paper therefore looks at child labour in cocoa production in Sekyere South District in the Ashanti region of Ghana. It focuses on the extent of children's involvement in cocoa production, the risks that they are exposed to, the aspect of cocoa production activities that children are actively involved and whether their involvement is free of charge or remunerated.

The involvement of children in the production of cocoa has been established by different scholars and organizations (Bass, 2004; ILO, 2008; Tulane University, 2009; 2015). There is widespread knowledge of working children and child labour in countries growing cocoa. Recent studies by the Tulane University (2015) found out that in 2013-2014 cocoa crop season, 2.26 million children were recorded as working in cocoa production in Côte d'Ivoire and Ghana combined. In addition, the study found out that 2.12 million and 2.03 million of the children were in child labour and hazardous work respectively. These figures show an increase in the number of children working and child labour in cocoa production when compared to the findings of Tulane University during its first survey in 200809 . The work activities in the cocoa supply chain can be clearly distinguished into pre-harvest (comprising land preparation, planting and farm maintenance), harvest (comprising cocoa harvest activities) and postharvest (comprising drying and transport of cocoa beans) phases (Tulane University, 2009). A look at Ghana's hazardous activities framework (MMYE, 2008), which is similar to that of other cocoa growing countries in West Africa shows that activities such as "clearing of forest and/ or felling of trees", "carrying heavy load beyond permissible carrying weight, i.e. above $30 \%$ of body weight for more than 2 miles (3 km)", "working with agrochemicals", "using machetes/long cutlasses for weeding", "harvesting overhead cocoa pods with harvesting hook", "breaking cocoa pods with breaking knife" are among the list of activities children are prohibited from. This has resulted in the reduction of children working in activities related to pre-harvest such as clearing trees, using machete etc. A large percentage of children are however still involved in the harvesting and post harvesting activities in Ghana and Côte d'Ivoire (Tulane University, 2015). Around 81\% of children working in cocoa production in Côte
d'Ivoire participated in the gathering and heaping of cocoa pods whiles $78 \%$ did the same in Ghana in 2013-2014 crop season (Tulane University, 2015).

Children working in cocoa production are at a risk of being exposed to multiple types of hazardous work (Tulane University, 2009; 2015). This risk can be physical or health related. Work overload, use of machetes, transportation of cocoa pods and participation in spraying pesticides and other agro-chemicals are some of the risk factors that children working in cocoa farms are frequently exposed to (ILO, 2007b; MMYE, 2008; Thorsen, 2012; Tulane University, 2015). A rapid assessment in Côte d'Ivoire, Cameroon, Ghana and Nigeria conducted by ILO (2007a), found out that the most common physical injuries that children working in cocoa production face were cuts from machetes or from contact with sharp sticks and twigs on the farm and the sharp edges of harvesting tools. This is an indication that child labour in cocoa production is real. However, the percentage of children who offer labour free of charge and those who offer labour for monetary reward or remuneration has not been thoroughly investigated within the cocoa industry and this gap is what the study sought to fill.

In Ghana, the government has been making frantic effort to eliminate child labour with the introduction of the National Plan of Action (NPA), which was endorsed by cabinet after being developed by a broad-base consultative process involving both the micro and macro levels in of the industry. This is one of the most vivid manifestations of the country's commitment to combat child labour, after the ratification of relevant international conventions such as the United Nation's Charter on the Rights of the Child (UNCRC), ILO Conventions on Minimum Age for admission into employment (Convention 138) and Worst Forms of Child labour (Convention 182). Ghana also buys into the African Charter on the Rights and Welfare of the Child (ACRWC). In Ghana's National Medium Term Development Plan (Ghana Shared Growth and Development Agenda-GSGDA), the NPA pulls together the various interventions that seek to address the child labour problem. Also, Part 5 of the children's Act, 1998 (Act 560) makes provision for the prohibition of exploitative child labour and addresses what is acceptable child work or light work. However, the Act falls short of the detail and procedure prescribed by the Convention No. 182 and its associated recommendation 190 which provide guidelines for the Worst Forms of Child Labour (WFCL). In other words, though Ghana has signed the Convention No. 182, the necessary recommendation under the convention is not being implemented by the government. 
This is as a result of the fact that some of the limitations of the nation's Children's Act. Under the National Plan of Action (NPA), there is a call for the review of the Children's Act to enhance its relevance and effectiveness. The provisions relating to the WFCL are woefully inadequate and therefore needs revision to be in tandem with the ILO Convention. There is, thus, a need to expand on the sectors listed in Section 91(2) of the Act, and to develop a framework that will clearly provide for the identification of hazardous tasks or activities within each of the identified sectors. Thankfully, as part of the implementation of the NPA, a comprehensive Hazardous Activity Framework (HAF) has been developed and validated by experts and stakeholders; and now waits for its formal adoption by the competent authority.

According to the national programme for the elimination of worst forms of child labour in cocoa production, about $84 \%$ of children working on cocoa farms in Ghana live with their parents, whilst $14 \%$ also live with their relatives. This is an ample indication that children in cocoa production in the country are not being exploited and therefore child labour policies of the ILO should be targeted towards what is seen as exploitative work of the host country.

\section{Methodology}

Sekyere South District, formerly Afigya Sekyere (the study area) is located in the North Central part of the Ashanti Region. It shares boundaries with five districts: namely Ejura-Sekyeredumase to the North, Sekyere West to the East, Sekyere East and Kwabre to the South and Offinso to the West. Specifically, the district lies between Latitudes $6^{\circ} 50^{\prime} \mathrm{N}$. and $7010^{\prime} \mathrm{N}$. and Longitudes $1040^{\prime} \mathrm{W}$. and $1025^{\prime} \mathrm{W}$. Figure 1.1 and 1.2 shows the district in both national and regional contexts respectively. The total land area of the District is 770 square kilometres. Figure 1 shows the map of the Sekyere South District and the communities that were selected for the study1.

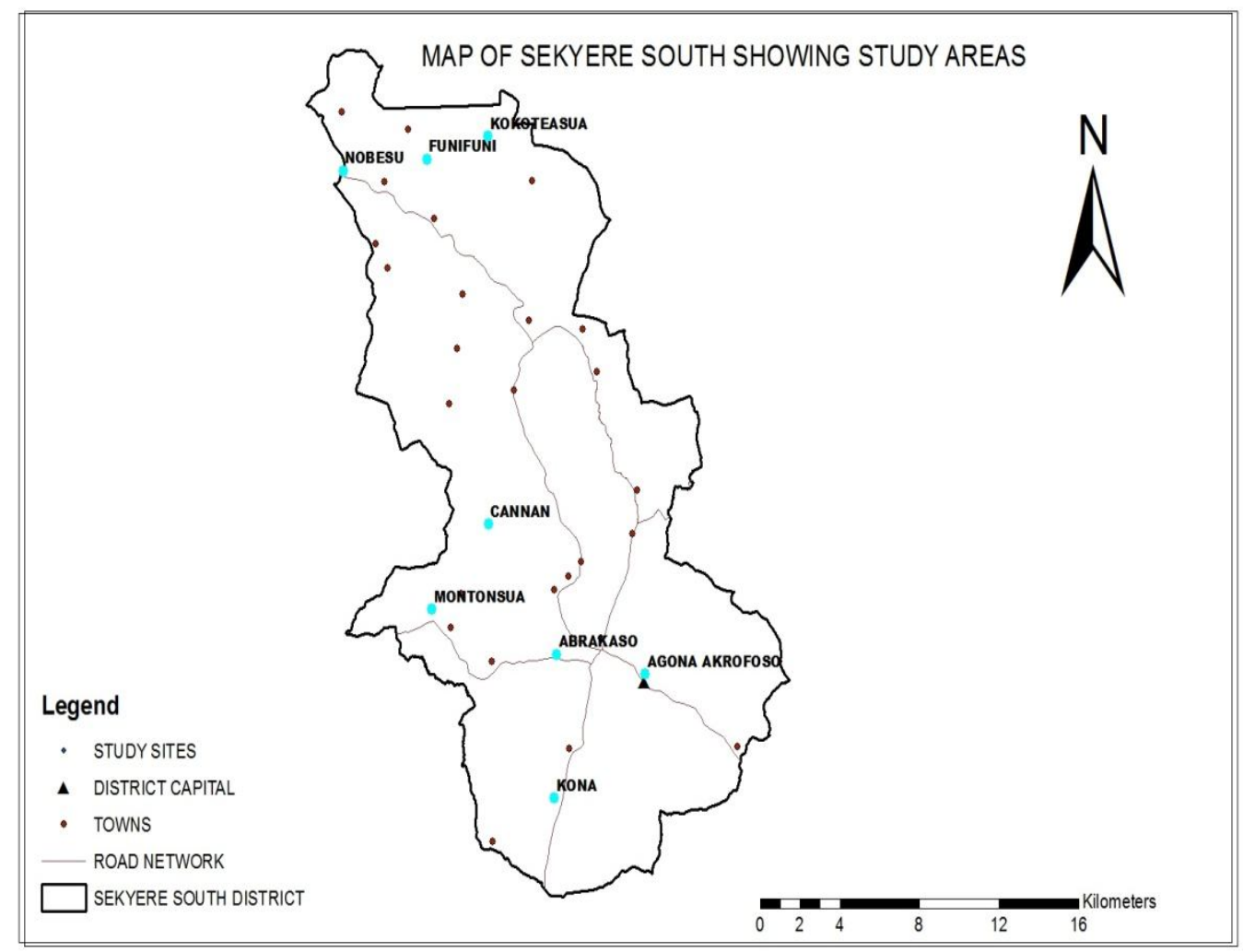

Fig. 1. Map of Sekyere South District showing the ten selected Communities used for the study.

Source: Sekyere South District Assembly and authors construct 
The study employed mix-method research design and adopted the case study approach. Thirty-two cocoa growing communities in the Sekyere South District were identified. Out of this, 10 cocoa farming communities were purposively selected based on the intensity of cocoa production and the extent of children's involvement in the production activities. Using Focus Group Discussions (FGDs), participant groups made up of women, men, children and opinion leaders were purposely selected from the 10 selected cocoa producing communities in the district with the help of Assemblymen in the electoral areas where the communities are located. Adult participants were selected by the Assemblymen based on the cocoa production levels (yields or output per crop season) and the extent of involvement of children on their cocoa farming activities. They were put into groups of six persons in each group. Semi structured questionnaires were employed to guide the discussions. Since the number of cocoa farmers in the 10 selected communities were not known, the formula for determining sample size when the population or sample frame is not known was used to arrive at approximately 68 cocoa farmers, i.e. $(\mathrm{Z} \text { score })^{2}\left(\mathrm{sd}(1-\mathrm{sd}) / \mathrm{M}^{2}\right.$ at $90 \%$ confidence level. Where $\mathrm{Z}$ score is a constant and at $90 \%$ confidence level is 1.645, sd is standard deviation and $\mathrm{M}^{2}$ confidence level $(90 \%=0.01)$. These farmers were not part of the focus group discussions but were selected with the help of cocoa purchasing clerks in the 10 communities and structured questionnaires were administered to them through face to face interviews to complement the qualitative data. Out of the 68 farmers only 50 agreed to take part of the study as subjects. The study also selected 68 children for face to face interview but could not administer the questionnaires to them because of lack of permission from their parents.

In addition, secondary information was sought from reports such the Sekyere South District Children's welfare report, Ghana's Children Act, 1998 (Act 560), Ghana' National Plan of Action on Child Labour, Domestic Workers Convention and Hazardous Activity Framework reports, journals, books and periodicals to beef up the primary data.

\section{Results}

All the farmers who participated in the survey agreed that children are actually involved in cocoa farming activities in the Sekyere South but indicated that child labour in the district comes in two forms. The first category is made up of children who help either their parents or guardians on their farms during non-school days, i.e. Saturdays and public holidays. This constitutes an aspect of the cultural and nonformal training. The second category comprises those children aged between 10 and 17 years who do minor jobs on the farm for monetary reward. Proportion of children in this category was low and quite insignificant.

\section{Types of Children's involvement in cocoa production}

The children in the 10 selected communities are involved in most of the cocoa production stages. Children are involved in some of the land preparation activities, which include: clearing of land and stumping, and children helping in the placing of plantain suckers into the dug holes during planting. Some of the children also do carry seedlings to the farm. Children above 14 years fetch water and help in the cooking on the farm whilst their parents do other activities. Others also carry fertilizers to the farm. The activity, which extensively involve children is gathering and carrying of the pods to the breaking site constitutes $92 \%$ of the children involve in cocoa farming in the selected communities. Some parents specifically do carry their children along to the farm to look after their younger siblings during vacations. About $72 \%$ of farmers do involve their children in carrying of fermented beans to the house for drying. This is an indication that the children are also equally involved in cocoa production as their parents but get no monetary reward.

\section{Extent of children's involvement}

All the farmers interviewed in the 10 communities; namely Nobesu, Funfuni, Kokoteasua, Abrakaso, Morso, Brofrudu, Canaan, Amenase, Kofikrom, Oppong Yaw and Akronfoso demonstrated knowledge about child labour and even child trafficking issues, indicating awareness as to what constitute child labour. They were also aware of the aspect of cocoa production activity that children were involved and production activities that the labour of children was paid for. This means that some children were employed specifically for certain production activities that attracted remuneration. Table 1 sum up the activities that children generally undertake on the farm and the aspect that farmers purposely use hired children's labour. 
Table 1. Farmers who involve children as labour and the type of activity that attract remuneration.

\begin{tabular}{lccc}
\hline Production Activity & $\begin{array}{c}\text { Number of } \\
\text { farmer who } \\
\text { involve } \\
\text { children }\end{array}$ & $\begin{array}{c}\text { Percentage } \\
\text { of farmers } \\
\text { who paid } \\
\text { for } \\
\text { children's } \\
\text { labour }\end{array}$ & $\begin{array}{c}\text { Percentage } \\
\text { of farmers } \\
\text { who } \\
\text { enjoyed free } \\
\text { labour of } \\
\text { children }\end{array}$ \\
\hline Carrying of cocoa seedling to the farm & 50 & 40 & 60 \\
Planting of seedling & 40 & - & 80 \\
Weeding and thinning & 45 & 12 & 82 \\
Carrying of fertilizer and fertilizer application & 46 & 8 & 84 \\
Fetching of water for spraying & 48 & 54 & 42 \\
Gathering and heaping of pods & 50 & - & 100 \\
Scooping of beans from pods & 50 & - & 100 \\
Carrying of fermented beans to drying mats & 48 & 4 & 92 \\
Cooking and fetching of water on the farm for parents & 50 & - & 100 \\
Drying of the beans & 43 & - & 86 \\
\hline
\end{tabular}

Source: Field survey March, 2016

Note: some of the rows do not add up to $100 \%$ and this is explained by the fact that not all the 50 farmers interviewed use children in some of the production activities that are paid for on the farm.

A significantly higher proportion of farmers in the 10 communities used children's labour in cocoa production (Table 1). Apart from carrying of cocoa seedlings to the farm, weeding and thinning, fetching of water for spraying on the farms and the carrying of fermented beans to drying mats for drying which attracted remuneration, all other cocoa production activities that children are involved do not attract remuneration. The reason is that they are the children of the farmers and are obliged to help their parents. To the farmers, it was also a way of training these children to take over from them when they are aged and can no longer care for the farms. These activities never in any way compromised the education of the children. The children who offer their labour for money actually have no relationship with the farmers. This category of children was looking for additional income to complement the efforts of their parents in addressing their educational needs. What can be deduced out of this is that children are involved in cocoa production in the Sekyere South District, but it is to the mutual benefit of both the parents and the children.

\section{Risk and lack of protective clothing}

Generally, both the farmers and the children do not protect themselves whiles working on the farm and the study tried to find out from the farmers the type of risks and injuries children working on their farms are pruned to. It was revealed that they are exposed to cocoa farming related dangers, such as snake bites, stumps piercing into their feet and being injured by sharp farm implements (as shown in Table 2).

Table 2. Casualties from cocoa farming activities among children.

\begin{tabular}{lcc}
\hline Type of injury & Number of children & Percentage of children \\
\hline Wounds from farm implements & 20 & 32.3 \\
Snakes bites & 6 & 9.7 \\
Stumps piercing into feet & 18 & 29 \\
Injury from carrying heavy loads & 6 & 9.7 \\
Chemical inhalation & 12 & 19.3 \\
Total & 62 & 100 \\
\hline
\end{tabular}

Source: Field survey march 2016

Note: These injuries are not mutually exclusive. Children involve in cocoa farming activities suffer from one or more of the injuries identified during the study.

The study revealed that the most common injury to children working in cocoa farms in the 10 communities is wounds from farm implements, (32.3\%), with stumps piercing into feet constituting (29\%) ranking second (Table 2). These children work on the farm bear-footed and therefore are susceptible to these dangers. This is not strange because most of the farmers interviewed do not wear any protective gear, let alone providing same for their children. Averagely, $46 \%$ of children working on cocoa farms in the 10 communities are casualties from cocoa production activities. 


\section{Summary of findings}

This section tries to summaries the findings of the study as follows:

- Children do help in the farm be it directly or indirectly and a majority of them offer free labour, which in a way help the farmers to expand their farms.

- Generally, the children do not protective clothing and boots whiles working on the farm thereby exposing them to farm injuries. This brings to the fore the possible dangers and risks such as injuries from farm implements, snake bites and stumps piercing into their feet that the children are exposed to.

- The study revealed that only few farmers involve children in production activities and paid for their labour. These activities are carrying of seedlings, fertilizers, and fermented beans.

- Most of the farmers complained about decrease in yields and the consequent poverty they are experiencing as a result of the abolition of child labour through campaigns being waged by NGOs, the nation's development partners, and the ILO.

\section{Implications and Conclusion}

The findings from the research has brought to fore some of the key issues regarding children's involvement in cocoa production activities. The study concludes by indicating that help from children and cocoa production in the Sekyere South District in the Ashanti Region are mutually inclusive. For this reason issues relating to children's involvement in the cocoa industry, must be addressed with caution. Quite a significant number of farmers in the district use their children on the farm, which is also a form of apprenticeship training for the children, who in the event of their parents growing old; will take over from them without necessarily compromising their education. They can go to school and obtain the necessary education and qualification but once they are interested in farming, they can also invest in cocoa farming and for that matter cocoa production when they know how to cultivate cocoa. Any attempt to remedy children's involvement in cocoa production will invariably affect production levels because of the free labour the children offer to their parents and the fact that the proceeds from the farms are also used to cater for the education of their children. The key issue is to evolve a system where children can work on their parent's farm during weekends and during schools vacations to enable them have a feel of both education and cocoa farming. Anything short of this will definitely affect cocoa production and thereby the government's attempt at improving cocoa production output in the country.

\section{References}

Augendra, B. 2008. Defining child labour: a controversial debate. Dev. Practice. 18(3): 385- 394.

Bass, L.E. 2004. Child Labor in Sub-Saharan Africa. Boulder, CO: Lynne Rienner Publishers. $213 \mathrm{p}$.

Basu, K. and Zarghamee, H. 2009. Is product boycott a good idea for controlling child labour? A theoretical investigation. J. Dev. Econ. 88 (2): 217- 220.

Emerson, P.M. and Souza, A.P. 2011. Is Child Labour Harmful? The impact of working earlier in life on adult earnings. Econ. Dev. Cultural Change. 59: 345- 385.

Franziska, H. 2009. The challenge of child labour in international law. Cambridge University Press. $18 \mathrm{p}$.

Humphries, J. 2010. Childhood and child labour in the British industrial revolution. Cambridge University. pp. 4-5.

ILO. 2007a. Rooting out child labour from cocoa farms. Paper No. 1: A synthesis report of five rapid assessments. Geneva: R. Rinehart, International Programme on the Elimination of Child Labour (IPEC), International Labour Organization (ILO). pp. 8-23.

ILO. 2007b. Eradication of forced labourGeneral survey concerning the forced labour convention, 1930 (No. 29), Geneva, International Labour Organisation (ILO). pp. 18-21.

ILO. 2008. Report III: Child Labour Statistics, 18th International Conference of Labour Statisticians, Geneva: International Labour Organization (ILO). pp. 1-10.

J ean-Marie, B. and Robinson, J.A. 2000. Is child labour inefficient? J. Political Econ. 108 (4): 663- 679.

MMYE. 2008. Hazardous child labour activity framework -for the cocoa sector of Ghana. Accra: Ministry of Manpower, Youth and Employment. pp. 23-29.

Ravallion, M. and Wodon, Q. 2000. Does child labour displace schooling? Evidence on behavioural responses to an enrolment subsidy. Econ. J. 110: 158-175.

Thorsen, D. 2012. Children working in commercial agriculture evidence from West and Central Africa. Dakar-Yoff, Senegal: UNICEF. pp. 9-10.

Tulane University. 2009. Third annual report, oversight of public and private initiatives to eliminate the worst forms of child labor in the cocoa sector in Côte d'Ivoire and Ghana. p. 71.

Tulane University. 2015. 2013-14 Survey Research on Child Labor in West African Cocoa Growing Areas. School of Public Health and Tropical Medicine, Tulane University. pp. 55-74.

Watson, A.M.S. 2008. The Child in International Political Economy: A Place at the Table. Routledge Francis and Taylor Group. 51 p. 